\title{
Hysteric Woman: A Study on The Yellow Wallpaper
}

\author{
"I'm sitting by the window in this atrocious nursery".
}

Shahnaz M. S.

Research Scholar, Department of English

The Zamorin's Guruvayurappan College

Kozhikode, Kerala, India

shenzzms@gmail.com

Dr. Rajani B

Research Guide, Associate Professor

Department of English

The Zamorin's Guruvayurappan College

Kozhikode, Kerala, India

Abstract

In an unquestionably patriarchal society, women who dissent, who had a voice of her own, one with strong affiliations towards social change were labelled as hysteric and mad. Their symptoms were thoughtfulness, deviation from social behavior, tendency to shout and express one's emotion, even getting angry were considered as symptoms of hysteria. A hysteric woman is a hopeless woman, the lost one; who needs to be locked up in an attic. The men had two extreme approaches towards these conditions. They either treated women as fragile beings, who need to be cared and nurtured under the protection of men. Or they termed "women with disease" as monstrous, insane, dangerous and despicable beings. These two approaches were unhealthy and were designed to preserve the superiority of masculine 
self over the feminine. These tags which were labelled on women came from their existential fear; 'the castration anxiety'.

Keywords: Hysteria, Feminism, Patriarchy, Mental Health, Feminine, Masculine, Castration Anxiety

Hysteric women or female hysteria was a common medical diagnosis during the $19^{\text {th }}$ century. This was described as exhibiting a wide array of symptoms, including anxiety, shortness of breath, fainting, nervousness, sexual desire, insomnia, fluid retention, heaviness in the abdomen, irritability, loss of appetite for food or sex, sexually forwarded behavior, and a "tendency to cause trouble for others". Though it is no longer recognized as a medical disorder, women with hysteric tendencies and melancholia were common throughout Europe for quite a long time. It's quite ironic that more women with symptoms of hysteria were diagnosed during the rise of feminist movements.

In an unquestionably patriarchal society woman who dissent, who had a voice of her own, one with strong affiliations towards social change were labelled as hysteric and mad. Their symptoms were thoughtfulness, deviation from social behavior, tendency to shout and express one's emotion, even getting angry were considered as symptoms of hysteria. A hysteric woman is a hopeless woman, the lost one; who needs to be locked up in an attic. The men had two extreme approaches towards these condition. They either treated women as fragile beings, who need to be cared and nurtured under the protection of men. Or they termed "women with disease" as monstrous, insane, dangerous and despicable beings. These two approaches were unhealthy and were designed to preserve the superiority of masculine self over the feminine. These tags which were labelled on women came from their existential fear; 'the castration anxiety'.

The nervousness, insomnia and anxiety one feels while incandescently working to let the world hear oneself; that's too when the world is hostile towards oneself, is unexplainable. 
The loneliness, the state of being ostracized, the ridicule that one has to experience while being a writer/reader/suffragist or a 'mere' woman is overwhelming and nerve wracking. Even an 'ordinary' woman has to undergo various levels of subjugation and hardship throughout her life which itself invites emotional instability.

One of America's first feminists Charlotte Perkins Gilman brought to light the issues afflicting women in the late $19^{\text {th }}$ and early $20^{\text {th }}$ century. Her writings were mostly inspired from her own life. She suffered serious bout of post- partum depression. She was born on July 3, 1860, in Hartford, Connecticut, to Mary Perkins and Frederic Beecher Perkins. During Charlotte's infancy, her father moved out and abandoned his wife and children, and the remainder of her childhood was spent in poverty.

Since their mother was unable to support the family on her own, the Perkins were often in the presence of her father's aunts, namely Isabella Beecher Hooker, a suffragist; Harriet Beecher Stowe, author of "Uncle Tom's Cabin" and Catherine Beecher, educationalist.

Her schooling was erratic: she attended seven different schools, for a cumulative total of just four years, ending when she was fifteen. Her mother was not affectionate with her children. To keep them from getting hurt as she had been, she forbade her children from making strong friendships or reading fiction. In her autobiography, The Living of Charlotte Perkins Gilman, Gilman wrote that her mother showed affection only when she thought her young daughter was asleep. Although she lived a childhood of isolated, impoverished loneliness, she unknowingly prepared herself for the life that lay ahead by frequently visiting the public library and studying ancient civilizations on her own. Additionally, her father's love for literature influenced her, and years later he contacted her with a list of books he felt would be worthwhile for her to read. 
She married Charles Stetson in 1884, and less than a year later gave birth to their daughter Katherine. Already susceptible to depression, her symptoms were exacerbated by marriage and motherhood. A good proportion of her diary entries from the time she gave birth to her daughter until several years later describe the oncoming depression that she has to face. This was an age in which women were seen as "hysterical" and "nervous" beings; thus when a woman claimed to be seriously ill after giving birth, her claims were sometimes dismissed.

She was advised to 'rest cure' which meant confining herself at home doing nothing. She was extremely unhappy with the treatment.Years later, she became a vocal critic of the treatment, and the doctor who administered this.

Charlotte Perkins Gilman died in 1935, but she remains today a provocative sociological writer; she makes us think, argue, and question our preconceptions, especially with regard to marriage and family. She was a pioneering sociologist, feminist pragmatist, author, and lecturer. Her writings remain as testimonies of her philosophy and life. She had been a path breaking inspiration to young women whose life were confined in the shells of 'hysteria'.

"The Yellow Wallpaper" by Gilman created feminist fireworks the moment it appeared in the January 1892 edition of the New England Magazine. The story is semiautobiographical. Much of the plot is inspired from a period in Gilman's own life. The short story takes the form of a secret diary written by a young married woman who is suffering from a "temporary nervous depression- a slight hysterical tendency". The diagnosis has been made by her husband, who also happens to be "a physician of high standing". In line with fashionable medical practice, "John" has prescribed a radical "rest cure" that involves separating the narrator from her small baby and confining her to the top- floor nursery of a rented country house: 
“I...am absolutely forbidden to 'work' until I am well again".

Gilman was writing about her own agonizing experience: five years earlier she was fell in postnatal depression and was sent to America's leading expert in women's mental health, Dr. Silas Weir Mitchell. His punishing regime for depressed middle-class female patients involved strict bed rest with no reading, writing, painting and, if it could be managed, thinking. His theory was grounded in the pervasive belief that if modern girls stopped wanting things- education, the vote but, above all, "work"- they would become happy, which is to say docile, again. Mitchell instructed Gilman to live as domestic a life as possible "and never to touch pen, brush or pencil as long as you live".

Gilman wrote later of her treatment, which felt more like a prison sentence, "I ... came perilously close to losing my mind".

This experience of Gilman repeats in "The Yellow Wallpaper". In the short story she states how horrifying it is to not able to decide one's own happiness, one's own saneness. She has been barred from doing any domestic chores, even looking after her new born baby. This worsens her depression instead of curing. She becomes a living person without life inside. Her memories and imagination were left to wild fancies. She is left with a yellow wallpaper in which she sees some bizarre patterns and designs. Day by day she gets annoyed by the wallpaper, she hates the color, the smell, everything about the wallpaper disgusts her. The wallpaper begins to absorb and control most of her thinking. She gets frustrated and asks John (her husband) to change the wallpaper. But he never takes it seriously.

"He said that after the wallpaper was changed it would be the heavy bedstead, and then the barred windows, and then that gate at the head of the stairs, and so on".

She is literally locked in her room, which she thinks previously was a nursery. The windows are barred. She doesn't like the room. She has said this many a time to her husband that she wants to change the room to downstairs. But he never heeds. Her husband and sister- 
in -law 'takes care' of her in turns. But both of them fails to give her the solace she needed. Too much of their 'care' even worsens her situation. John is not at home most of the time. She always wishes she could go outside and get fresh air. She wishes if she had been living near people, so that while she looks out of the window she could actually see people walking around, instead of empty lanes and garden. According to her,"John is away all day, and even some nights when his cases are serious." She says, "I am glad my case is not serious!"

John never takes her seriously. For him she is just a woman who has a slight nervous weakness. He considers her as a girl with no decision making capacity. His words and actions were sugar coated, but he never tries to address the real concerns and fears. He even calls her little girl (What is it, little girl?").

The suffocation and boredom of being confined inside a room gives way to serious mental issues. The treatment prescribed by her husband proves futile and even heightens her mental deterioration. Strangely, the yellow wallpaper becomes her only solace. She becomes increasingly obsessed with the wallpaper. The wallpaper dwells in her mind. She says, "I'm getting really fond of the room in spite of the wallpaper. Perhaps 'because' of the wallpaper."

She sees different geometrical patterns inside the wallpaper. Later the wallpaper starts shaking and moving. She finds out that there is a woman locked up inside the wallpaper. The woman shakes the bars of the prison making the wallpaper move. Towards the end of the short story she says that there is not just one woman who is locked up in the wallpaper, but there are numerous women creeping and crawling inside the wallpaper on searching the way out.

According to her, the woman only comes out in the night, when her husband is asleep and her sister- in -law is nowhere to be seen. 
Initially she shared her disgust and fear towards the wallpaper with her husband. But he rejected it as mere fancy, and never intends to change the wallpaper even though she desperately wishes to change it.

“...but John has cautioned me not to give way to fancy in the least. He says that with my imaginative power and habit of story- making, a nervous weakness like mine is sure to lead to all manner of excited fancies, and that I ought to use my will and good sense to check the tendency. So I try".

Despite her earnest struggle to not 'give way' to fancy and imagination, the 'banned' writer at last finds out how miserable and despicable kind of a life she is leading. The protection and care she received were nothing but shackles of domination. This realization made her see her fellow comrades, who lived the same fate. They could only taste the fresh air during the night, when the world is asleep. When the world is awake, they are again in shackles.

She gets obsessed with the yellow wallpaper to the point that she doesn't want to come out of the room.

"For outside you have to creep on the ground, and everything is green instead of yellow. But here I can creep smoothly on the floor, and my shoulder just fits in that long smooch around the wall, so I cannot lose my way."

She finds her own way of expression. Gilman shows how a woman, confined in the four walls of a nursery, a woman who was rejected creative pleasure finds her own space. A space to express and articulate oneself. A space to translate oneself to other self.

She found her way out, at last. Alone.

"I've got out at last", said I, "In spite of you and Jane? And I've pulled off most of the paper, so you can't put me back!”

She burns the walls of her prison into ashes. 
"Now why should that man have fainted? But he did, and right across my path by the wall, so that I had to creep over him every time!”

Isn't this what 'men' have been doing for ages? Faint right across the woman's path. So that, she wouldn't move forward. But only the one who dares to creep over him reaches where she intends. So, who is the one with 'the tendency to cause harm to others'? Let the history answer.

"The Yellow Wallpaper" by Gilman, which was written centuries back, still echoes the truth about women's servitude. The fainted husband who has failed to acknowledge the reality is a representation of modern man. When one's perception of reality and 'actual reality clashes it destroys one's ability of reasoning. That crashes one's understanding of things. Gilman rightfully shows how the patriarchal world cracks down when their perception of reality is blurred.

The short story remains as one of the defining works of feminist literature. Gilman wrote this story at a time when writing about women's mental and physical health were considered radical. The work is an important testimony about women's role in society; how a woman is being valued in patriarchal world. 


\section{Works Cited}

Primary Source

Gilman, Charlotte Perkins. The Yellow Wallpaper. The New England Magazine, 1892.

Secondary Sources

Bronfen, Elisabeth. The Knotted Subject. 1997.

Showalter, Elaine. Hystories: Hysterical Epidemics and Modern Culture.1997.

Cixous, Helene. The Laugh of Medusa. 1976.

Freud, Sigmund. The Uncanny. Penguin Books. 2003

Gilman, Sander. Hysteria Beyond Freud. 1993.

Kristeva, Julia. The Powers of Horror: An Essay on Abjection. Columbia UP. 1980.

Mitchell, Juliet. Psychoanalysis and Feminism. 1974. 